\title{
CULTURAL FUNDAMENTALS OF THE CONTENT OF SCHOOL LITERARY EDUCATION: HISTORICAL AND PEDAGOGICAL DISCOURSE
}

\author{
Nataliya Hohol \\ Candidate of Pedagogical Sciences, Assistant Professor, Doctoral Student at the Department \\ of History and Philosophy of Education, Institute of Pedagogy of the National Academy \\ of Pedagogical Sciences of Ukraine, Ukraine \\ e-mail: natashagogol75@gmail.com,orcid.org/0000-0003-0780-6237 \\ Zoya Turyanytsya \\ Candidate of Pedagogical Sciences, Deputy Director for Educational Work of Detached \\ Structure Unit "Professional Pedagogical Specialty College of Oleksander Dovzhenko \\ Hlukhiv National Pedagogical University", Ukraine \\ e-mail: tzvtum@ukr.net,orcid.org/0000-0003-4526-757X
}

Hameni Blaise

Ph.D., Institute of Vocational Training for Development, Douala-Akwa, Cameroon e-mail: bhameni@yahoo.fr, orcid.org/0000-0002-9922-7947

\section{Summary}

The article notes that in the modern humanitarian paradigm of school literary education, competencies, the importance of a comprehensive approach to the use of cultural influence of related arts on the formation of a young personality is realized. The importance of using productive theoretical and methodological achievements of scientists on this problem for the effective development of modern theory and practice of teaching literature is substantiated. Scientific and methodical works of Ukrainian and foreign scholars (G. Belenky, T. Brazhe, V. Grechynska, E. Kolokoltseva, N. Miretska, Z. Starkova) on the problem of interdisciplinary and interdisciplinary interaction in school literary education are considered. It is proved that in the scientific and methodological work of Ukrainian and foreign scientists the method of complex use of related arts (painting, graphics, sculpture, music, cinema, etc) as effective means of implementing the culturological approach in the lessons of Russian literature is substantiated. It is emphasized that the optimal forms, methods and techniques of working with the means of related art proposed by leading scientists on the basis of their dialogical interaction contribute to the deepening of knowledge of literary and art history, students' comprehension of a literary work as a unique text of culture, specifics, the formation of skills to analyze and interpret literary works in an artistic context. It is concluded that the theoretical and methodological guidelines of scientists of the late twentieth century on this issue have become the basis for constructive and critical understanding of the problem of cultural orientation of the content of school literary education in the early XXI century.

Keywords: literature lesson, culturological approach to the study of Russian literature, related arts, scientific and methodological achievements of Ukrainian and foreign scholars, school reform in 1984-1990.

DOI: https://doi.org/10.23856/4016 


\section{Introduction}

In the humanitarian paradigm of school literary education is increasingly aware of the importance of an integrated approach to the use of cultural influence of related arts on the formation of young personality, which is regulated in a number of government documents, namely: National Doctrine of Education in Ukraine in the XXI century, Concept «New Ukrainian School», The State Standard of Basic and Complete General Secondary Education. In the Concept of Literary Education, the implementation of the culturological line involves the study of literature in the context of culture and art (literature as the art of speech), consideration of literary works in relation to painting, music, cinema and other arts, the use of culturological principle, determining the place of literature among other arts and in the spiritual culture of the people and humanity (Concept, 2011).

Competence guidelines of school literary education indicate the need to determine the culturological basis of the content of school literary education in the historical and pedagogical thought of the school educational reform of 1984-1990, which is to study the genesis of pedagogical and methodological ideas to determine the culturological basis of school literature, substantiation of the importance of using productive theoretical and methodological achievements of scientists on this problem for the effective development of modern theory and practice of teaching literature.

\section{Analysis of recent research and publications.}

Constructive-critical comprehension of the problem of culturological bases of the content of literary education is presented in the works of scientists-teachers: I. Balkharova, E. Bondarevska, M. Bastun, V. Gura, I. Zyazyun, I. Kolmolgorova, O. Rudnytska, V. Slastyonina, I. Yakimanskaya and other scientists. In school literary education, this problem has been consistently developed in scientific research of leading domestic and foreign scholars, including G. Achkasova, K. Bogachev, M. Boretsky, A. Vitchenko, N. Voloshin, E. Voloshchuk, G. Gladyshev, A. Gradovskiy, V. Domanskiy, S. Zhyla, D. Zatonskiy, M. Zhulynskiy, O. Isayev, 3. Kyryliuk, J. Klymenko, Y. Kovbasenko, L. Miroshnychenko, I. Moiseev, D. Nalyvayko, O. Nikolenko, L. Nezhiva, E. Pasichnyk, O. Pokatilova, O. Pronkevych, S. Safaryan, N. Svirina, O. Slonivska, Y. Sultanov, B. Shalaginov, K. Shakhova, Z. Shevchenko, T. Yatsenko and others.

Scientific investigations of Ukrainian and foreign scholars demonstrate both the diversity of certain aspects of this topic and the richness of modern approaches to its understanding, which are to justify the need to diversify methods and techniques, types and forms of work with the text of the work of art, development of methodological system introduction of innovative technologies of teaching Ukrainian and foreign literature etc.

Today, a wide range of scientific and methodological ideas of scientists of the $1980 \mathrm{~s}-$ 1990s on the implementation of a culturological approach to teaching literature by means of interdisciplinary and inter-artistic interaction is not the object of systematic research by modern scientists. Thus, in the conditions of competence guidelines of modern school literary education, the objective need for retrospective analysis, actualization and creative realization of accumulated progressive methodological experience in the practice of teaching literature on the cultural basis of the period of educational reform 1984-1990 became relevant. 


\section{The purpose of the article}

The purpose of the article is to substantiate the culturological bases of the content of school literary education, presented in the scientific and methodological thought of the period of the educational reform of 1984-1990.

\section{The reasons for the intensification of the culturological direction in school literary education during the period of educational reform in 1984-1990}

The formation of literary education and the formation of theory and practice of teaching literature has always been an urgent problem of the domestic school. In the 80's - 90's of the twentieth century among scientists and researchers intensified the problem of finding optimal ways to develop school education. This provoked a lively discussion about humanities education, during which the issues of teaching literature, literary education, its role and significance, and what a teacher-linguistic should be, etc. were discussed. With the beginning of the reform in 1984, changes took place in school literary education, which were related to the system and integrity of the humanities, as well as the development of interdisciplinary and interworkartship links through the integration of scientific knowledge.

Thus, the actualization of interdisciplinary and inter-artistic interaction in the theoretical and methodological works of scientists and practical implementation by teachers of linquistic and became the reasons for the intensification of culturological direction in school literary education in the 80's - 90's of XX century. The reform of secondary and vocational schools in 1984 opened up certain opportunities for cooperation in the study of Russian, Ukrainian, foreign, and the literature of the peoples of the USSR. The main task of the reform was «improving art education and aesthetic education of students, the need to develop a sense of beauty, to form high aesthetic tastes, the ability to understand and appreciate works of art $<\ldots>$ use for this purpose every subject, especially literature...» (On the reform of general education, 1984: 48). Thus, the strengthening of the role and significance of inter-artistic and inter-subject connections in the study of literature was facilitated by the objective processes that took place in the culture of the last decades of the Soviet era.

\section{Substantiation of culturological bases of the content of school literary education in scientific and methodical works of foreign scientists}

The teaching of literature in high school was based on the study of works by prominent artists of Russian, Ukrainian, Soviet and foreign classics in general. Among linguists, interest in the use of related arts in literature lessons was revived, a work of art was seen as a work of verbal art in dialogic interaction with other arts (fine arts, music, cinema, theater etc.), art culture began to be realized "not just as a background but as a semantic component of a literary work and the basis of its interpretation" (Melnyk, 2013: 7).

Leading Ukrainian and foreign scholars, researchers, active teachers of linguists (L. Aizerman, O. Bandura, H. Belenky, T. Brazhe, N. Voloshyna, V. Grechynska, M. Kudryashov, S. Kurganov, T. Kurdyumova, S. Lavlinsky, V. Marantsman, E. Pasichnyk, V. Troitsky, O. Frolova, M. Cherkesova etc.) were engaged in substantiation of culturological bases of the content of school literary education. Scholars actively considered the implementation of a culturological approach to the teaching of literature in general secondary education, updated the methods of problem-based learning, as well as the concept of «immersion» of students in the culture of the era whose literature was studied and so on. 
Thus, the foreign researcher H. Belenkiy saw the solution to the problem of improving the literary education of high school students in the introduction to the humanities cycle of basic subjects of art history (or aesthetics). The scientist emphasized the need for high school students to study theoretical art and literary concepts, noting that the knowledge gained by students based on the perception and analysis of related arts will help them better understand the originality of a literary work as an art of speech.

Defining the cultural vision of the general purpose of studying literature at school $\mathrm{H}$. Belenky insisted on involvement of schoolchildren in samples of domestic and world art culture. In the textbook «Involvement in the Art of Speech» the scientist emphasized the importance of the relationship of types and forms of aesthetic activity of the reader, whose experience of communication with the book must be complemented by audience and listening experiences, artistic knowledge and creative skills. "The wider and deeper the reading experience», said the scientist, «the easier and more intensely the secrets of music or painting are grasped. Conversely, a person who is experienced in the fine arts will not remain deaf to the art of speech" (Belenky, 1990: 166).

Foreign researcher N. Miretska insisted on the need for a holistic mastery of the individual's cultural heritage, including the arts. The scholar argued that "the teaching of any art does not require a sharp separation, separation from other arts but constant associations with them, parallels" (Miretskaya, 1989: 32). It is now widely believed that the study of literature on the basis of inter-artistic interaction opens wide opportunities for individualization of the educational process, because in many children «the emergence of interest in the word is associated with visual impressions that resonate with verbal art. And how important it is to create in the lesson the mood necessary for the perception of the book and to cause not just general attention but individual "inclusion in the empathy of the text" (Miretskaya, 1989: 31).

Foreign researcher E. Kolokoltsev professionally developed a method of using related arts (painting, graphics, music, samples of masters of artistic reading, verbal and graphic visualization) in lessons of Russian literature. In "Art in Literature Lessons", the scientist points out the importance of turning to related arts for the aesthetic and literary development of young people, the formation of a holistic view of inter-artistic connections and the specifics of literature as the art of speech (Kolkoltsev, 1991).

The method of using works of related arts by E. Kolokoltsev was based on the method of comparing them with literary works and facts, which allows to deepen students' understanding of the specifics of literature as an art form. The use of this method in literature lessons, according to the scientist, helps students to penetrate into the atmosphere of the work of art, develops thinking, expands emotional experience, enriches oral and written speech, promotes better perception and understanding of the work of art (Kolkoltsev, 1991: 5). At the same time, the use of paintings and graphics, listening to music is an effective means of implementing inter-subject links in literature lessons, serves not only as a means of improving students' literary education, but also affects their understanding of the laws of art, expands aesthetic horizons (Kolkoltsev, 1991: 5-6).

In the textbook "Art in Literature Lessons" (Kolkoltsev, 1991) E. Kolokoltsev presents a method of using related arts in lessons of Russian literature in the study of various literary genres. The scientist-methodologist acquaints students with the art of illustration as an effective means for students to deeply understand the content and form of a work of art. The use of portrait painting, reproductions of paintings by artists of the brush, according to the scientist, is appropriate when studying the biography of the writer, analysis of literary works and students mastering theoretical and literary concepts on the lessons in the development of coherent speech and more. 
E. Kolokoltsev's statements about the use of musical art in the lessons of Russian literature are correct. Methodist advocated the need for careful selection of factual material for literature lessons, appealed to the emotional impressions and feelings of students while listening to music, stressed the need to discuss samples of music with appropriate teacher commentary, use the method of conversation when working on related works of art etc. (Kolokoltsev, 1991: 143-163).

Foreign scholar T. Braje brought up the issue of studying a literary work in a broad cultural context on the basis of dialogical interaction of related arts. In the textbook "Problems of studying Russian literature in the 9th grade of evening school" the scientist substantiates the theoretical provisions for the analysis of a literary work on the basis of inter-artistic interaction, emphasizes the need to consider the work of verbal art in the context of the writer, literary and cultural processes (Braje, 1986).

In the scientific and methodological explorations of the foreign scientist Z. Starkova the search for effective forms, methods and techniques of working with the text of a work of art in the lessons of Russian literature on the basis of dialogical interaction of related arts is presented. Thus, in the textbook "Commonwealth of Arts in Literature Lessons», the scientist highlights the general trends in finding ways to implement a dialogic relationship of related arts (painting, music, film and theater) in the literary education of students. The problem of interaction of related types of art in the lessons of Russian literature is considered by the scientist on the basis of "three levels of dialogical construction", namely: aesthetic, ideological and moral (Starkova, 1988: 4-5). According to the scientist, the comparative analysis of artistic trends used in the literature lesson, which reproduces the principles of reflecting the world through the prism of the artist's creative vision, will contribute to the formation of worldviews and education of moral qualities of the individual. Thus, the community of arts in the literature lesson not only intensifies the pedagogical process, but also promotes students' interest in related art, the desire to understand the means of creating images in various arts, the implementation of cultural development of young people.

\section{The problem of realization of culturological approach to teaching literature in the works of Ukrainian researchers}

In the context of the subject field of our study, the pedagogical views of Ukrainian scientist V. Grechynska are relevant, emphasizing the expediency of using works of related arts in lessons of Russian literature on the basis of their ideological and thematic unity and compositional and stylistic features. Such interaction, according to the scientist, will contribute to the accumulation of students' knowledge in the field of literary criticism and art history, expand the experience of working with relevant reference literature, the formation of skills to compare, confront, express evaluative attitudes to the perceived art canvas and more. At the same time, work with works of related arts in literature lessons should ensure the implementation of educational tasks of the lesson, promote better learning by students, be accessible to students of a certain age, deepen students' theoretical and literary knowledge, develop their ability to work independently on paintings and graphics.

$\mathrm{V}$. Grechynska raised the issue of the amount of literary and art information that should be mastered by primary and secondary school students in the lessons of Russian literature. The scientist also singled out the skills that students have when mastering works of related art, namely: to understand and retell the content of a painting or illustration, to determine the 
theme and idea of works of fine art; in the unity of form and content to analyze the plot-compositional construction of reproductions of paintings, graphics, photos of sculptural monuments; to establish common and different in several paintings of similar subjects, to evaluate the skill of the artist's use of pictorial and expressive means; on a practical level to distinguish works of painting and graphics, their types and genres (portraits, landscapes, household paintings, etc.) and so on (Grechinskaya, 1983).

However, in 8 th -10 th grades, according to V. Grechynska, in accordance with the requirements of literary education, work on the replenishment of literary and art information should be systemic, which will undoubtedly affect students' interest in paintings, teach them if necessary to turn to art literature in order to expand their own horizons, as well as to form the ability to express their own attitude to works of painting and graphics in order to better understand literary works. In grades 8-10, students' skills and abilities are expanded and improved, which affects the «reading» of paintings, verbal drawing on the picture, analysis of illustrations to literary works of one or more artists, writing works based on the considered masterpieces of art (Grechinskaya, 1983: 66-67). Thus, the obtained information of historical, literary and art nature and acquired skills will help expand students' horizons, form cultural competence, nurture the need to read literary works for aesthetic pleasure, stimulate interest in the achievements of other cultures and more.

Of professional interest to us is the algorithm of analysis of a literary work proposed by V. Grechynska in unity with related works of art, namely: establishing a connection between a literary work and illustrations; identification of common and different motives and images in the illustrations of different artists to the submitted work of art; expressing students' evaluative judgments based on the comparison of several illustrations; formation of students' ability to compare illustrations with literary works, to express an evaluative attitude to the analyzed paintings etc. (Grechinskaya, 1983: 79).

In this textbook, the scientist emphasizes the balance in the selection of related art in order to solve literary problems of the lesson. In accordance with the topics of Russian literature lessons proposed by the program, the scientist professionally presents a list of paintings, individual editions of albums with submitted works of fine arts, visual aids (slides, films, sound reproduction of individual scenes performed by theater actors, etc.), outlines the purpose and methods of their application stages of the lesson, as well as developed indicative questions and tasks that should be used in the lesson when working on works of related arts (Grechinskaya, 1983). Thus, the study of works of art in conjunction with related arts, the scientist considered as a powerful source of art information.

\section{Conclusions}

During the educational reform of 1984-1990, the teacher had the opportunity to present the teaching of literature as a holistic system, to predict the results of their work and activities of students, to ensure effective solution of educational problems of the course. The guidelines produced by Ukrainian and foreign scholars became an important methodological guideline for Methodist scholars of the late XX - early XXI century in determining the effective factors for the implementation of the culturological approach in the study of Ukrainian and foreign literature; development of a methodical system of culturological analysis of works of literature, substantiation of synthesis of study of literary text and works of other kinds of art; disclosure of socio-cultural, moral and ethical, humanitarian, aesthetic orientation of the educational process. Thus, Ukrainian and foreign scholars have substantiated the feasibility of synthesizing 
the study of literary texts and works of other arts, emphasizing the importance of revealing the features of works of art, literary phenomena and facts in a broad cultural context. We see the prospect of further scientific research in the analysis of scientific and methodological achievements of leading Ukrainian and foreign scholars on the problem of substantiation of cultural bases of the content of school literary education of the last decade of the twentieth century - the beginning of the XXI century.

\section{References}

Belen'kij G. I. (1990) Priobshhenie k iskusstvu slova : (Razdum'ja o prepodavanii literatury v shkole) [Introduction to the art of words: (Reflections on the Literature teaching at school)]. Moskva : Prosveshhenie. 192 s. [in Russian].

Brazhe T. G. (1986) Problemy izuchenija literatury v 9 klasse vechernej shkoly: Kniga dlja uchitelja [The issues of Literature studying in the Grade 9 of an evening school: A book for a teacher]. Moskva: Prosveshhenie. 175 s. [in Russian].

Grechinskaya V. S. (1983) Naglyadnost na urokah russkoj literatury : posobie dlya uchitelya [Visibility in the lessons of Russian literature: a guide for the teacher]. Kiev : Radyanska shkola. 152 s. [in Russian].

Kolokol'cev E. N. (1991) Iskusstvo na urokah literatury : posobie dlja uchitelja. [Art in Literature classes : a book for a teacher]. Kiev : Rad. shk. 208 s. [in Russian]

Koncepciia literaturnoii osvity, 26 sichnia 2011 roku (2011) [The concept of literature education, January 26, 2011]. URL: http://osvita.ua/legislation/-Ser_osv/13508. [in Ukrainian].

Melnyk A. (2013) Vnesok L. F. Miroshnychenko u rozvytok problemy navchannia zarubizhnoii literatury u kulturolohichnomu konteksti [L. F. Miroshnychenko's contribution to the development of Foreign Literature teaching in the culturological context]. Vsesvitnia literatura $v$ suchasniy shkoli. no. 5 (387). 7-12 [in Ukrainian].

Mireckaja N. V. (1989) Soprjazhenie: kompleksnaja rabota po jesteticheskomu vospitaniju $v$ shkole : Iz opyta raboty : kn. dlja uchitelja [Conjugation: complex work on aesthetic education at school : From work experience : a book for a teacher.]. Moskva : Prosveshhenie. 206 s. [in Russian].

O reforme obshheobrazovateljnoj y professyonaljnoj shkolbl (1984) [On the reform of the secondary and vocational schools. Journal of documents and materials]. Sbornyk dokumentov y materyalov. Moskva: Polytyzdat. 112 s. [in Russian].

Starkova Z. S. (1988) Sodruzhestvo iskusstv na urokah literatury: Iz opyta raboty: Kniga dlja uchitelja [Interaction of arts in Literature lessons: From work experience: A book for a teacher]. Moskva: Prosveshhenie. 160 s. [in Russian]. 